\title{
Lesson learnt from nuclear disasters - health hazards \& its prevention
}

\section{Abstract}

The United Nations Disaster Relief Organization (UNDRO) defines a disaster as "a serious disruption of the functioning of a society, causing widespread human, material, or environmental losses which exceed the ability of the affected society to cope using its resources."

A number of nuclear disasters have occurred in the world which includes the worst disaster of Hiroshima and Nagasaki bombing, the Chernobyl disaster and the Fukushima tragedy.

Acute Radiation Syndrome also is known as radiation sickness caused by a high dose of penetrating radiation. The three classic ARS Syndromes are: Bone Marrow Syndrome, Gastrointestinal (GI) Syndrome and Cardiovascular (CV)/ Central Nervous System (CNS) syndrome. Survival is extremely unlikely in the case of GI syndrome whereas death may occur within two weeks in the case of cardiovascular syndrome.

Human beings are badly affected by head to toe by radiation exposure. There may be $\mathrm{f}$ hair loss in clumps, Damage to nerve cells leading to seizures, thyroid carcinoma, increased long term risk for leukemia, lymphoma, sterility, and radiation burn, etc.

The best prevention of radiation sickness is to minimize the exposure dose. This can be achieved by increasing the distance from the radiation source and early evacuation. We have to find out and respect the regulations regarding production, transport, handling and storage of radioactive substances. In the case of nuclear fallout, stay in house/ shelter as advised. If a nuclear explosion occurs- take shelter behind a solid wall and if you are outside, lie down in a ditch facing the ground and protect your face with your arms.

Sustained Information, Education and Communication (IEC) activities should be carried out vigorously to sensitize the people of health hazards of radiation exposure that can occur in the health sector or due to nuclear fallout that may be accidental or intentional.
Volume 9 Issue 4 - 2020

\section{M.Athar Ansari}

Department of Community Medicine, Aligarh Muslim University, India

Correspondence: M.Athar Ansari, Community Medicine, Aligarh Muslim University, Aligarh, India, Tel +91989726762I, Email atharansari7@rediffmail.com

Received: December 31, 2019 | Published: August 07, 2020

\section{Introduction}

United Nations Disaster Relief Organization (UNDRO), defines disaster is "an event, concentrated in time and space, in which a community undergoes severe danger and incurs such losses to its members and physical appurtenances that the social structure is disrupted and the fulfillment of all or some of the essential function of the society is prevented" ${ }^{1-6} \mathrm{~A}$ number of nuclear disasters have occurred in the world which includes the worst disasters of Hiroshima and Nagasaki bombing, the Chernobyl disaster and the Fukushima tragedy. A list of disaster is given in Table 1.

\section{Adverse effects of radiation exposure}

Radiation disasters affect the whole body from head to toes (Table 2). ${ }^{7}$

Table I Worst Nuclear Disasters in the world ${ }^{2,3,4,5,6}$

\begin{tabular}{lllc}
\hline Date & Location & Description of accident or incident & Deaths \\
\hline Aug. 6 1945 & Hiroshima, Japan & Atom Bomb dropping by USA & $1,40,000$ \\
Aug.9 1945 & Nagasaki, Japan & Atom Bomb dropping by USA & 7
\end{tabular}

Sept. 29, 1957 Mayak, Kyshtym, Soviet Union

Sellafield aka Windscale

Oct. 10, 1957 fire, Cumberland, United Kingdom
The Kyshtym disaster was a radiation contamination accident (after a chemical explosion that occurred within a storage tank) at Mayak, a Nuclear fuel reprocessing plant in the Soviet Union.
Estimated 200 possible 6 cancer fatalities 6

A fire at the British atomic bomb project (in a plutonium-production-reactor) damaged the core and released an estimated 740 terabecquerels of iodine- I3I into the environment. A rudimentary smoke filter constructed over the main outlet chimney successfully prevented a far worse radiation leak.
0 direct, estimated up to 240 possible cancer 5 victims 
Table Continued...

\begin{tabular}{|c|c|c|c|c|}
\hline Date & Location & Description of accident or incident & Deaths & INES Level \\
\hline Jan. 3, 1961 & $\begin{array}{l}\text { Idaho Falls, Idaho, United } \\
\text { States }\end{array}$ & $\begin{array}{l}\text { Explosion at SL-I prototype at the National Reactor } \\
\text { Testing Station. All } 3 \text { operators were killed when a } \\
\text { control rod was removed too far. }\end{array}$ & 3 & 4 \\
\hline Jan.21, 1969 & $\begin{array}{l}\text { Lucens } \\
\text { reactor, Vaud, Switzerland }\end{array}$ & $\begin{array}{l}\text { On January } 21,1969 \text {, it suffered a loss-of-coolant } \\
\text { accident, leading to meltdown of one fuel element and } \\
\text { radioactive contamination of the cavern, which before } \\
\text { was sealed. }\end{array}$ & 0 & 4 \\
\hline Dec.7, 1975 & Greifswald, East Germany & $\begin{array}{l}\text { Electrical error in Greifswald Nuclear Power } \\
\text { Plant causes fire in the main trough that destroys } \\
\text { control lines and five main coolant pumps }\end{array}$ & 0 & 3 \\
\hline Jan. 5,1976 & $\begin{array}{l}\text { Jaslovské } \\
\text { Bohunice, Czechoslovakia }\end{array}$ & $\begin{array}{l}\text { Malfunction during fuel replacement. Fuel rod ejected } \\
\text { from reactor into the reactor hall by coolant (CO2). }\end{array}$ & 2 & 4 \\
\hline $\begin{array}{l}\text { March 28, } \\
1979\end{array}$ & $\begin{array}{l}\text { Three Mile } \\
\text { Island, Pennsylvania, United } \\
\text { States }\end{array}$ & $\begin{array}{l}\text { Loss of coolant and partial core meltdown due to } \\
\text { operator errors and technical flaws. There is a small } \\
\text { release of radioactive gases. See also Three Mile Island } \\
\text { accident health effects. }\end{array}$ & 0 & 5 \\
\hline April 26, 1986 & Chernobyl, Ukrain & $\begin{array}{l}\text { A flawed reactor design and inadequately trained } \\
\text { personnel led to a failed backup generator test. This } \\
\text { test led to a power surge which overheated the fuel } \\
\text { rods of reactor no. } 4 \text { of the Chernobyl power plant, } \\
\text { causing an explosion and meltdown }\end{array}$ & $\begin{array}{l}28 \text { direct, } 19 \text { not } \\
\text { entirely related and } \\
\text { I } 5 \text { minors due to } \\
\text { thyroid cancer, as of } \\
2008 \text {. Estimated up to } \\
4000 \text { possible cancer } \\
\text { deaths. }\end{array}$ & 7 \\
\hline I3 Sept. 1987 & Goiania, Brazil & $\begin{array}{l}\text { Forgotten radiotherapy source was taken from an } \\
\text { abandoned hospital site }\end{array}$ & $\begin{array}{l}4 \text { deaths and } 249 \\
\text { contaminated }\end{array}$ & 5 \\
\hline Sept. 30, 1999 & Ibaraki Prefecture, Japan & $\begin{array}{l}\text { Tokaimura nuclear accident killed two workers, } \\
\text { and exposed one more to radiation levels above } \\
\text { permissible limits. }\end{array}$ & 2 & 4 \\
\hline Feb. 16, 2002 & $\begin{array}{l}\text { Oak Harbor, Ohio, United } \\
\text { States }\end{array}$ & $\begin{array}{l}\text { Severe corrosion of reactor vessel head forces } \\
24 \text {-month outage of Davis-Besse reactor }\end{array}$ & 0 & 3 \\
\hline April 10, 2003 & Paks, Hungary & $\begin{array}{l}\text { Collapse of fuel rods at Paks Nuclear Power Plant unit } \\
2 \text { during its corrosion cleaning led to leakage of } \\
\text { radioactive gases. It remained inactive for } 18 \text { months. }\end{array}$ & 0 & 3 \\
\hline Aug. 2004 & Fukui Prefecture, Japan & $\begin{array}{l}\text { Steam explosion at Mihama Nuclear Power Plant kills } \\
4 \text { workers and injures } 7 \text { more }\end{array}$ & 4 & I \\
\hline July 25, 2006 & Forsmark, Sweden & $\begin{array}{l}\text { An electrical fault at Forsmark Nuclear Power } \\
\text { Plant caused multiple failures in safety systems that had } \\
\text { the reactor to cool down }\end{array}$ & 0 & 2 \\
\hline Feb. 26,2010 & Mayapuri, New Delhi, India & $\begin{array}{l}\text { An AECL Gamma cell } 220 \text { research irradiator owned } \\
\text { by Delhi University was auctioned to a scrap metal } \\
\text { dealer }\end{array}$ & I & 4 \\
\hline $\begin{array}{l}\text { March II, } \\
2011\end{array}$ & Fukushima, Japan & $\begin{array}{l}\text { A tsunami flooded and damaged the plant's } 3 \text { active } \\
\text { reactors, }\end{array}$ & $\begin{array}{l}\text { land } 3+\text { labour } \\
\text { accidents; plus a } \\
\text { broader number } \\
\text { of primarily ill or } \\
\text { old people from } \\
\text { evacuation stress }\end{array}$ & 7 \\
\hline
\end{tabular}


Table 2 Effects of radiation on body

\begin{tabular}{|c|c|c|}
\hline \multirow[t]{7}{*}{ Head and Neck } & . & Fatigue \\
\hline & · & Hair loss \\
\hline & . & Mouth changes \\
\hline & . & Skin changes \\
\hline & $\cdot$ & Taste changes \\
\hline & . & Throat changes, such as trouble swallowing \\
\hline & . & Less active thyroid gland \\
\hline \multirow[t]{10}{*}{ Pelvis } & . & Diarrhoea \\
\hline & . & Fatigue \\
\hline & · & Hair loss \\
\hline & $\cdot$ & Nausea and vomiting \\
\hline & $\cdot$ & Sexual problems (men) \\
\hline & · & Fertility problems (men) \\
\hline & . & Sexual problems (women) \\
\hline & · & Fertility problems (women) \\
\hline & . & Skin changes \\
\hline & . & Urinary and bladder changes \\
\hline \multirow[t]{9}{*}{ Rectum } & . & Diarrhoea \\
\hline & . & Fatigue \\
\hline & · & Hair loss \\
\hline & . & Sexual problems (men) \\
\hline & · & Fertility problems (men) \\
\hline & · & Sexual problems (women) \\
\hline & . & Fertility problems (women) \\
\hline & . & Skin changes \\
\hline & . & Urinary and bladder changes \\
\hline \multirow[t]{6}{*}{ Stomach and Abdomen } & · & Diarrhoea \\
\hline & . & Fatigue \\
\hline & · & Hair loss \\
\hline & · & Nausea and vomiting \\
\hline & . & Skin changes \\
\hline & . & Urinary and bladder changes \\
\hline
\end{tabular}

Acute radiation syndrome: The three classic ARS Syndromes are: ${ }^{8}$

i. Bone Marrow Syndrome -may occur with a dose between 0.7 and 10 Gy. Mild symptoms may occur as low as 0.3 Gy or 30 rads. The cause of death is the destruction of the bone marrow, leading to infection and hemorrhage.

ii. Gastrointestinal Syndrome -may occur with a dose between 10 and 100 Gy. Survival is extremely unlikely. Destructive and irreparable changes within the alimentary canal may occur. Death usually happens within two weeks.

iii. Cardiovascular (CV)/ Central system nervous (CNS) syndrome, the complete syndrome will usually occur with a dose greater than 50 Gy though some symptoms may occur as low as 20 Gy or 2000 rads. Death due to the collapse of the cardiovascular system occurs within three days. The basal cell layer of the skin is broken by radiation. Hair follicles could also be damaged causing hair loss.

\section{Radiation protection}

The best prevention for radiation syndrome is to scale back the exposure dose or to chop the rate through increasing the space from the area and time reduction.

Distance: Increasing distance from the radiation source will reduce exposure. Distance can sometimes be effectively increased by 
means as simple as handling a source with forceps and not fingers or evacuation of the people to safer distant areas.

Time: The longer humans are subjected to radiation, the larger the dose absorbed. The exposed person should be taken out of the place of disaster as early as possible.

\section{Prevention of adverse effects 9}

Prevention of adverse effects can be done through the following measures:

\section{General precaution and safety measures}

i. Find out and respect the regulations regarding production, transport, handling and storage of radioactive substances.

ii. Keep family emergency kit ready. It includes identity papers and private medicines

iii. Plan and organize your probable stay in protection shelter or basement especially if living during a neighbourhood of a atomic power plant.

iv. Keep calm and don't panic.

v. Listen to radio/ T.V. and respect the recommendations.

\section{When the extent of radioactivity increases}

i. Keep calm and don't panic.

ii. Listen to radio/ T.V. and respect the recommendations.

iii. Stay in house/ shelter/ basement.

iv. Close the air vents, door and windows and switch off the air conditioner.

v. If outside, protect your mouth and nose with a wet cloth and seek refuge within the nearest shelter.

vi. Don't use phones to avoid the overloading the telecommunication system.

vii. Eat only stored food.

viii. Bottled water could also be used.

ix. Avoid going into the stricken area.

x. Don't use vehicles so as to not slow the relief operations/ ambulance services.

xi. If an atomic explosion occurs- take shelter behind a solid wall if you're outside.

xii. Lie in a ditch facing the bottom and protect your face together with your arms.

\section{After the incident}

i. First, two days after the explosion is most dangerous.

ii. Stay in a shelter as long as fortnight.

iii. Take for brief trips with protective measures if needed.

iv. Evacuation could also be needed.

v. Help to arrange evacuation with civil and military personnel.

vi. Help neighbors, injured, sick, children, pregnant women and aged.

\section{Preparing a secure haven}

i. The entire city or neighborhood could become endangered by radiological hazards.

ii. Plan a haven at your residence.

iii. Select an inner room with the smallest amount number of windows and doors.

iv. The space should be large with the attached bathroom.

v. Close all doors, windows and air vents with plastic sheets (6 $\mathrm{mm}$ minimum) and seal with pressure-sensitive tape.

vi. The water-soaked cloth should be wont to seal gaps under doors.

\section{Safe haven equipments}

i. Protective equipment - mask, waterproof clothing, longsleeved shirts, long trousers, raincoats, boots, gloves, etc.

ii. Food and water system for 3 days.

iii. Emergency equipment - flashlights, battery operated radio, extra batteries, care kit, plastic, tape, soap, etc.

iv. Miscellaneous items - prescribed medicines, eyeglasses, blankets, important papers, etc.

\section{Conclusion}

Apart from nuclear disasters, radiation is additionally getting used within the health sector within the X-ray imaging, computerized tomography scans, diagnostic and therapeutic medicine. Radiation medicine has been revolutionized within the sort of brachytherapy, the gamma knife, and linear accelerators, technologies that are utilized in diagnosis and treatment. On the opposite hand, radiation's benefits for human health are often measured in thousands of lives saved and even greater numbers of persons whose quality of life has been improved annually by these technologies. Albeit the utilization of radiation in medicine offers enormous benefits, however, it also poses potential risks to patients, medical personnel, and therefore the general public. We should always use radiation in medical sciences judiciously taking all the precautions and medicine. Sustained Information, Education and Communication (IEC) activities should be administered vigorously to sensitize the people of health hazards of radiation exposure which will occur within the health sector or due to nuclear fallout which will be accidental or intentional.

\section{Funding}

None.

\section{Acknowledgments}

None.

\section{Conflicts of interest}

The author declares that there was no conflict of interest.

\section{References}

1. Disaster Management A Conceptual Analysis. 2020.

2. International Atomic Energy Agency. The Radiological accident in Goiania. 1988. 
3. UNSCEAR. Sources and effects of ionizing radiation. UNSCEAR 2008;II:64-65.

4. UNSCEAR. Chernobyl accident: UNSCEAR's assessments of the radiation effects .2020 .

5. Katariya M. 5 of the most disastrous nuclear accidents in history that shook the world. 2019
6. Dey AB, Mohanan S, Damodaran D, et al. Radiation accident at Mayapuri scrap market, Delhi, 2010. Radiat Prot Dosimetry. 2012;151(4):645-651.

7. NIH. Radiation Therapy Side Effects. National Cancer Institute. 2018.

8. CDC. Acute Radiation Syndrome: A Fact Sheet for Clinicians. Centres for Disease Control and Prevention. 2018.

9. ICDO. Radiological. International Civil Defence Organisation. 2020. 